\title{
Editorial
}

\section{Latin American Perspectives on Datafication and Artificial intelligence: Traditions, Interventions, and Possibilities}

Perspectivas latinoamericanas sobre la datificación y la inteligencia artificial: tradiciones, intervenciones y posibilidades

Perspectivas latino-americanas sobre datificação e inteligência artificial: Tradições, intervenções e possibilidades

Emiliano Treré1
Stefania Milan

DOI: 10.5294/pacla.2021.24.3.1

Para citar este editoral / to reference this editorial / para citar este editorial Treré, E. \& Milan, S. (2021). Latin American Perspectives on Datafication and Artificial intelligence: Traditions, Interventions, and Possibilities. Palabra Clave, 24(3), e2431. https://doi.org/10.5294/pacla.2021.24.3.1

Gracias por todo, Sergio

Contemporary democracies across the globe are increasingly challenged by the diffusion of invasive data technologies and the rise of intelligent systems, more commonly known as Artificial Intelligence (AI). Citizens welcome these technologies with both hopes for bettering society and fears of the growing intrusion of the industry and the state into the private life of individuals. While "Western" scholarship has advanced several conceptual tools to understand these developments (see, among others, Lyon, 2018; van Dijck et al., 2018; Zuboff, 2019), the engagement of Latin American scholarship in these themes has been limited as of this date.

This Special Issue zooms in on perspectives on datafication and AI provided from and within the Latin American continent. This move is particularly urgent in virtue of two observations. On the one hand, while

\footnotetext{
https://orcid.org/0000-0002-2496-4571. Cardiff University, United Kingdom. treree@cardiff.ac.uk

https://orcid.org/0000-0002-9314-2889. Universiteit van Amsterdam, Netherlands. s.milan@uva.nl
} 
technological innovation in datafication and AI indiscriminately affects individuals and social groups across the globe, it lands distinctly in different societies (Milan \& Treré, 2019). Thus, what is specific to datafication and $\mathrm{AI}$ in Latin America? What experiences and cases can contribute to how smart technologies are progressively integrated into the region? In which ways can methodologies rooted in Latin American traditions help us investigate the impact of datafication and AI?

On the other hand, we argue, Latin American traditions in both research and praxis - think for example of critical ecology (Gadotti, 1990; Martinez-Alier, 1991) and liberation pedagogy (Dussel, 1973; Freire, 1970) — have much to offer to our understanding of the evolution of the information ecosystem. What specific contributions emerge from Latin American scholarship to our understanding and theorizing of datafication and AI? What conceptual frameworks can come to the rescue, and what conceptual bridges can be built between Latin American scholarship and other approaches? How can we expand or update existing Latin American frameworks to capture current trends and challenges?

Foregrounding these critical questions, this introductory essay argues for the value of Latin American perspectives in understanding the most recent technology and information developments. It is structured as follows. Firstly, it briefly illustrates why critical and decolonial traditions that have emerged in the region are of paramount importance locally and globally, thus deserving amplified attention and circulation. Secondly, it offers an analytical matrix that can assist in interpreting ongoing changes and challenges, including selected Latin American thinkers. Finally, the essay illustrates the content of the Special Issue.

\section{Why Latin America?}

The manifold contributions of the Latin American school of communication to understanding and theorizing media cultures and communicative practices have only recently started to be recognized in Anglophone scholarship. For thinkers of the caliber of Freire (1970), Martín-Barbero (1987), Verón (1998), and more recently Rodríguez (2001), Waisbord (2001) and 
Escobar (2008), who have been acknowledged beyond the continent, many other key contributors remain in the shadows. This is not only due to existing mechanisms of circulation of knowledge focused on the Euro-Western centric episteme (see Mignolo, 2011), but also to the over-influence of English as lingua franca that adds to the "sterilization of scientific work" and "limits the encounters between Western theory and scientific cultures rooted in other languages" (Suzina, 2020, p. 171).

Nevertheless, Latin American scholarship is awash with productive venues to address datafication and AI-related dynamics — so is its community practice. Latin America might be one of the most unequal regions of the world, but it has nurtured one-of-a-kind grassroots activism over the centuries. Together with local critical scholarly thinking, this movement's praxis is still today "pushing the boundaries of what it means to pensar desde el Sur [think from the South]" (Rodríguez, 2020). Fortunately, a wave of latter publications dialoguing with Latin American traditions (see, amongst many, Barranquero \& Baeza, 2017; Enghel \& Becerra, 2018; Harlow, 2017; Pertierra \& Salazar, 2019; Sierra Caballero \& Gravante, 2017; Stephansen \& Treré, 2020; Treré, 2019) has updated and expanded the reach of the region's unique media and cultural research, showcasing the contributions of Latin American communication studies to global media research. This is part of an ongoing attempt to "de-Westernize" and "decolonize" concepts and debates in a broad agenda of issues, which progressively permeates communication scholarship too (Waisbord \& Mellado, 2014).

Latin American interventions, we argue, are of value primarily for their ability to go beyond the mere exposure of systemic injustice with roots in colonialist exploitation and to offer productive venues for social change centered on the empowerment of individuals and communities. Promoting a critical and decolonial approach, the Special Issue aims to face the challenge of producing "innovative theoretical arguments that capitalize on the wealth of empirical lines of research and the unique intellectual tradition in the region" (Waisbord, 2014, p. 12). 


\section{A matrix to map Latin American approaches to datafication and $\mathrm{Al}$}

While this collection promotes and highlights theoretical and methodological pluralism, here we offer an analytical matrix that may help to make sense of the complexity of theories and cases. We propose to map Latin American perspectives on datafication and AI along two theme lines. The first line identifies the "what" (or "building blocks") of studying datafication and AI. The second line focuses on the "how" and seeks to bring into dialogue potential interpretative lenses to understand the "what" (see Milan \& Treré, 2021 for a detailed illustration). The three building blocks, which can be studied as a whole or in isolation, are infrastructure (or the material dimension), imaginaries (identifying how people make sense of and relate to technology), and practices (or the agentic dimension of what people do with technology). By way of example, Martín-Barbero (1987) helps us explore both imaginaries and practices; Rodríguez empowers us to understand infrastructure and practices; Reguillo (2017) encourages us to look at the interrelationships between the three blocks.

The three interpretative lenses we have identified, amongst the many possible, include decoloniality and race, which has deep roots in the Latin American tradition (e.g., Quijano, 2007); feminist (and more recently intersectional) theory, which has seen a "titanic" production in the region (Bard Wigdor \& Artazo, 2017), and pluriversal thinking, described as a "tool for reimagining and reconstructing local worlds" (Escobar, 2018, p. xvi) —and its ability to open up to "Southern" epistemologies (Santos, 2014).

\section{In this Special Issue}

In their article "Descolonizando los sistemas algorítmicos: diseño crítico para la problematización de algoritmos y datos digitales desde el Sur", Tironi and Valderrama reflect on the lessons learned in the "Algorithmic Identities" interdisciplinary project, tasked with understanding how personhood is re-configured in times of algorithms and data. The authors use the app prototype "Big Sister" to emulate central platform algorithmic profiling and recommendation systems as a social research device. The develop- 
ment of this prototype produced knowledge from a critical and decolonial perspective. Relying on digital trace interviews with prototype users, the authors reflect on the role of algorithms in their own lives and shed light on how people in Chile understand, inhabit, and shape algorithms daily. Drawing on insights from authors such as Escobar, Martín-Barbero, and Freire, Tironi and Valderrama argue that prototyping an app can contribute to "problematizing" the approach to datafication and algorithmic systems in Latin America.

In her article "Algoritmização de estereótipos raciais em bancos de imagens," Carrera presents a critical study of the image banks Getty Images and Shutterstock to understand whether the tagging processes of these search devices reveal algorithmic modes of reproduction of colonial mentalities about black women. Based on Patricia Hill Collins' concept of "controlling images," Carrera examines the images of Jezebel, Mammy, and Sapphire, underlining that the stereotype of black female subjectivity emphasizes narratives of subordination, exploitation, and animalization of female figures at the service of coloniality. Carrera shows how various forms of algorithmic coloniality permeate these banks, which tend to frequently label images of black women adhering to colonial standards of representation of sexuality, labor, and violence.

In "Datificación en contextos de corrupción," Barreneche, LombanaBermúdez, and Ramos-Martín situate the implementation of big data and AI within the "data for development" agenda in Latin America, where social asymmetries and structural corruption-inherited from colonization - translate into automation in data-driven systems historically subject to manipulation and data corruption. The authors examine two cases of malfunctioning in the information infrastructures of social assistance programs in Colombia (namely, Ingreso Solidario and Sisben) and draw on Latin American critical theory to illuminate the processes of datafication in these cases. They call into question data universalism and urge to overcome technocentric views, shifting the focus to the moments when technologies fail, local socio-technical imaginaries, and the political agency of those who resist their normative control. 
In their article "Unravelling Resistance: Data Activism Configurations in Latin American Civil Society," Aguerre and Tarullo investigate the evolution of resistance practices by Latin American civil society organizations in a context of pervasive datafication. They ask how these practices relate to the overall notions of symbolic domination denounced by the Latin American School of Communication. Although the problems surrounding datafication are still being explored by civil society organizations in the region, the authors demonstrate that signs of vitality are already showing in broader debates around human rights, community development, and media policies. The study identifies these organizations' key themes underlying datafication efforts, assessing how they shape resistance practices and their perceptions of asymmetrical power relations. While some patterns can be inscribed in existing conceptualizations surrounding resistance practices and data activism, this work singles out new conceptual and empirical approaches to face the challenges posed by a datafied society.

In "Autoridades interpretativas: una perspectiva teórica sobre datificación y producción de sentido," Gindin, Cingolani, and Rodriguez-Amat engage with Verón's perspective as a window into theoretical and empirical opportunities for the critical discussion of datafication. The authors reflect on the Veronian data production, circulation, and recognition processes to de-naturalize the idea that data are neutral or compact. Verón's approach helps make visible the conditions from which data are attributed, turning them into socially and culturally situated discursive constructs. In opposition to other Anglo-Saxon perspectives more prevalent in academia-i.e., Hall's encoding/decoding model—this article proposes to revisit Verón's description of the poor match between sense and circulation as an alternative way of dealing with the processes of interpretation that turn data into discourses. Therefore, it aims to enrich current debates on the discriminatory effects of datafication.

In their article "From Data Journalism to Artificial Intelligence," deLima-Santos and Salaverría start from the assumption that given the relative novelty and complexity of implementing AI in journalism, few areas have managed to deploy tailored AI solutions in the media industry. They thus investigate the hurdles and obstacles of deploying computer vision 
news projects - a sub-set of AI-in a leading Latin American news organization, the Argentine newspaper La Nación. Relying on participant observations and interviews, the authors highlight four main difficulties in implementing computer vision projects that involve satellite imagery: the lack of high-resolution imagery, the unavailability of technological infrastructure, the absence of qualified personnel to develop such codes, and the lengthy and costly implementation that requires significant investment. The essay concludes with a discussion of the centrality of AI solutions in the hands of big tech corporations.

In “O chão de fábrica (brasileiro) da inteligência artificial," Grohmann and Fernandes Araújo analyze Brazilians' work in global AI platforms, focusing on Appen and Lionbridge. They highlight the role of communication and data production for AI, exposing labor conditions and complexities as the factory floor. Relying on interviews with workers and observation in WhatsApp and Facebook groups, the authors explore workers' perceptions on five categories: hiring processes, time tracking and difficulties proving hours worked, lack of infrastructural reliability, work strategies and definition, and, finally, understanding of AI. In contrast to conceptions based on digital labor universalism, the two scholars underline the geopolitics of AI platform labor. The material conditions of data production and the role of communication among workers stand out as emerging and complex solidarities, like fissures and cracks, to devise strategies that deal with AI platform labor.

To conclude, we also would like to bring to the readers' attention two key procedural issues. Firstly, it is worth noting that this Special Issue is not exhaustive but intends to be a conversation starter. Latin America scholarship and praxis, we maintain, are well-positioned to critically scrutinize the political and cultural uses and consequences of technology and infrastructure-which, besides illuminating regional specificities, can also help us interpret cases and challenges beyond the Latin America region. Secondly, this Special Issue, in the tradition of the journal, is presented to you in three languages in recognition of the fact that language is more than a system of conventional signs to refer to our physical reality-it enforces a specific cognitive view of the world. 


\section{References}

Bard Wigdor, G., \& Artazo, G. (2017). Pensamiento feminista latinoamericano: Reflexiones sobre la colonialidad del saber/poder y la sexualidad. Cultura y Representaciones Sociales, 11(22). http://www.scielo.org.mx/ scielo.php?script=sci_arttext\&pid=S2007-81102017000100193\#B28

Barranquero, A. C., \& Baeza, C. S. (2017). Latin American Critical Epistemologies toward a Biocentric Turn in Communication for Social Change: Communication from a Good Living Perspective. Latin American Research Review, 52(3), 431-445. https://doi. org/10.25222/larr.59

Dussel, E. (1973). Para una ética de la liberación latinoamericana. Volumen I. Siglo XXI.

Enghel, F., \& Becerra, M. (2018). Here and There: (Re)Situating Latin America in International Communication Theory, 28(2), 111-130.https:// doi.org/10.1093/ct/qty005

Escobar, A. (2008). Territories of Difference. Place, movements, life, redes. Duke University Press. https://doi.org/10.1215/9780822389439

Escobar, A. (2018). Designs for the Pluriverse. Radical Interdependence, Autonomy, and the Making of Worlds. Duke University Press.

Freire, P. (1970). Pedagogia do oprimido. Edições Paz e Terra.

Gadotti, M. (1990). Pedagogia da terra. Petrópolis.

Harlow, S. (2017). Liberation Technology in El Salvador: Re-appropriating Social Media among Alternative Media Projects. Palgrave MacMillan.

Lyon, D. (2018). The Culture of Surveillance: Watching As a Way of Life. Polity Press.

Martín-Barbero, J. (1987). De los medios a las mediaciones. Gustavo Gili. 
Martinez-Alier, J. (1991). Ecology and the Poor: A Neglected Dimension of Latin American History. Journal of Latin American Studies, 23(3), 621-639. https://doi.org/10.1017/S0022216X0001587X

Mignolo, W. D. (2011). The darker side of western modernity: Global futures, decolonial options. Duke University Press. https://doi. org/10.1215/9780822394501

Milan, S., \& Treré, E. (2019). Big Data from the South(s): Beyond Data Universalism. Television \& New Media, 20(4), 319-335. https:// doi.org/10.1177/1527476419837739

Milan, S., \& Treré, E. (2021). Big Data From the South(s): An Analytical Matrix to Investigate Data at the Margins. In D. Rohlinger \& S. Sobieraj (Eds.), The Oxford Handbook of Sociology and Digital Media. Oxford University Press. DOI: https://doi.org/10.1093/oxfordhb/9780197510636.013.7

Pertierra, A. C., \& Salazar, J. F. (Eds.). (2019). Media cultures in Latin America: key concepts and new debates. Routledge. https://doi. org/10.4324/9780429425127

Quijano, A. (2007). Coloniality and modernity/rationality. Cultural Studies, 21(2-3), 168-178. https://doi.org/10.1080/09502380601164353

Reguillo, R. (2017). Paisajes insurrectos: jóvenes, redes y revueltas en el otoño civilizatorio. NED ediciones.

Rodríguez, C. (2001). Fissures in the Mediascape. An International Study of Citizens' Media. Hampton Press.

Rodríguez, C. (2020). Introduction. In H. Stephansen \& E. Treré (Eds.), Citizen Media and Practice: Currents, Connections, Challenges. Routledge. https://doi.org/10.4324/9781351247375-2

Santos, B. D. S. (2014). Epistemologies of the South: Justice Against Epistemicide. Routledge. 
Sierra Caballero, F., \& Gravante, T. (2017). Networks, Movements \& Technopolitics in Latin America: Critical Analysis and Current Challenges. Palgrave MacMillan. https://doi.org/10.1007/978-3-319-65560-4

Stephansen, H. \& Treré, E. (2020). Citizen Media and Practice: Currents, Connections, Challenges. Routledge. https://doi. org/10.4324/9781351247375-2

Suzina, A. C. (2020). English as lingua franca. Or the sterilisation of scientific work. Media, Culture \& Society, 43(1), 171-179. https://doi. org/10.1177/0163443720957906

Treré, E. (2019). Hybrid Media Activism. Routledge. https://doi. org/10.4324/9781315438177

van Dijck, J., Poell, T., \& de Waal, M. (2018). The Platform Society. Public Values in a Connective World. Oxford University Press. https://doi. org/10.1093/oso/9780190889760.001.0001

Verón, E. (1998). La semiosis social: Fragmentos de una teoría de la discursividad. Gedisa.

Waisbord, S. (2001). Family Tree of Theories, Methodologies and Strategies in Development Communication. Rockefeller Foundation.

Waisbord, S. (2014). United and fragmented: Communication and media studies in Latin America. Journal of Latin American Communication Research, 4(1), 1-23.

Waisbord, S., \& Mellado, C. (2014). De-westernizing Communication Studies: A Reassessment. Communication Theory, 24(4), 361-372. https://doi.org/10.1111/comt.12044

Zuboff, S. (2019). The Age of Surveillance Capitalism. Profile Books. 